\title{
Winter-spring recruitment patterns of epiphytic harpacticoid copepods in a temperate-zone seagrass bed
}

\author{
Donald G. Webb*, Timothy R. Parsons \\ Department of Oceanography, University of British Columbia, Vancouver, British Columbia, Canada V6T 1Z4
}

\begin{abstract}
Harpacticoid copepods inhabiting a seagrass (Zostera marina L.) bed on Roberts Bank, British Columbia, Canada, were sampled every 2 wk from late January to mid July in 1986 and 1987. Samples were taken of seagrass leaves and the underlying sediment. The epiphytic copepod community at this study site was composed of typical temperate genera (e.g. Dactylopodia, Harpacticus, Mesochra, Tisbe, Zaus). Total copepod abundance on the leaves generally exceeded that in the sediment. Densities on seagrass leaves were markedly lower in 1987 than in 1986. Temporal patterns of abundance of individual species were different between years, contrasting with the stability of successional patterns in sediment-dwelling harpacticoid communities. Some seagrass-dwelling copepod populations may be seeded in the spring from sediment-dwelling individuals. Also, possible movement from the leaf surface to the sediment was observed for 1 species. This study underscores the importance of sampling multiple subhabitats in seagrass beds when assessing the dynamics of the epiphytic copepod community.
\end{abstract}

\section{INTRODUCTION}

Harpacticoid copepods are usually the numerically dominant meiofaunal group inhabiting the surfaces of marine intertidal and subtidal macroalgae (e.g. Colman 1940, Wieser 1952, Mukal 1971, Pallares \& Hall 1974, Beckley \& McLachlan 1980, Hicks 1980, Johnson \& Scheibling 1987), although high algal sediment loads may favour the dominance of other groups such as nematodes (Hicks 1985). In the northern hemisphere, representative families of epiphytic harpacticoids are the Harpacticidae, Tisbidae, and Thalestridae (Hicks 1980, 1985). The Porcellidiidae are abundant in the southern hemisphere (Hicks 1977). However, little information is available on the structure of harpacticoid copepod communities inhabiting aquatic angiosperms such as seagrasses. Especially lacking are analyses at the species level and descriptions of temporal patterns of abundance. Since

\footnotetext{
- Present address: Department of Oceanography, Dalhousie University, Halifax, Nova Scotia, Canada B3H 4J1
}

harpacticoids are often a primary prey resource for fishes inhabiting seagrass beds (see Gee 1989), information on species-specific abundance patterns is of obvious importance for tracing trophic relationships within seagrass systems.

Initial reports of harpacticoid populations on seagrass leaves were simple records of presence and correlation with obvious plant characteristics [e.g. epiphytic algal biomass (Nagle 1968, Lewis \& Hollingworth 1982) and distance along individual leaves (Caine 1980, Novak 1982)]. The first comparative data of harpacticoid abundances on seagrass leaves and in underlying sediments were provided by Bell et al. (1986) who demonstrated that leaves, on a per unit sediment area basis, harboured harpacticoid densities equal to or greater than the sediments. In temporally sporadic samples from a Zostera bed in New Zealand, Hicks (1986) clearly showed that leaf and sediment samples contained different dominant species with typical algal fauna predominating on the leaves. However, individuals of epiphytic species were found in sediment samples. 
This paper presents detailed data on temporal patterns of abundance over a 6 mo period - winter to early summer - in 2 consecutive years of individual harpacticoid copepod species inhabiting seagrass leaves in the Strait of Georgia, British Columbia, Canada. Since individuals of primarily epiphytic species may also live in or on the sediment, sediment samples were also taken concurrently. These are, to our knowledge, the first detailed data on temporal patterns of abundance of seagrass-dwelling harpacticoid copepods. This sampling duration is significant in that it spans the period when epiphytic species are recruiting to the seagrass leaves after the winter. Our objective was to describe the successional patterns of harpacticoid species abundance during this period and to assess the potential role of the sediment as a source of individuals to seed the epiphytic community.

\section{MATERIALS AND METHODS}

Samples of Zostera marina leaves and underlying sediments were collected at Stn $\mathrm{H}$ on Roberts Bank, British Columbia, Canada $\left(49^{\circ} \mathrm{N}, 123^{\circ} \mathrm{W}\right.$ ) (Fig. 1). This area is vegetated with the seagrasses $Z$. marina $L$. seaward and $Z$. japonica Aschers. and Graebn. along its landward extent [see Harrison (1987) for a detailed description of vegetation patterns]. Stn $H$ was located within the main body of the $Z$. marina bed and was in a shallow subtidal area. Approximately $5 \mathrm{~cm}$ of water covers the sediment surface at low tide (D'Amours

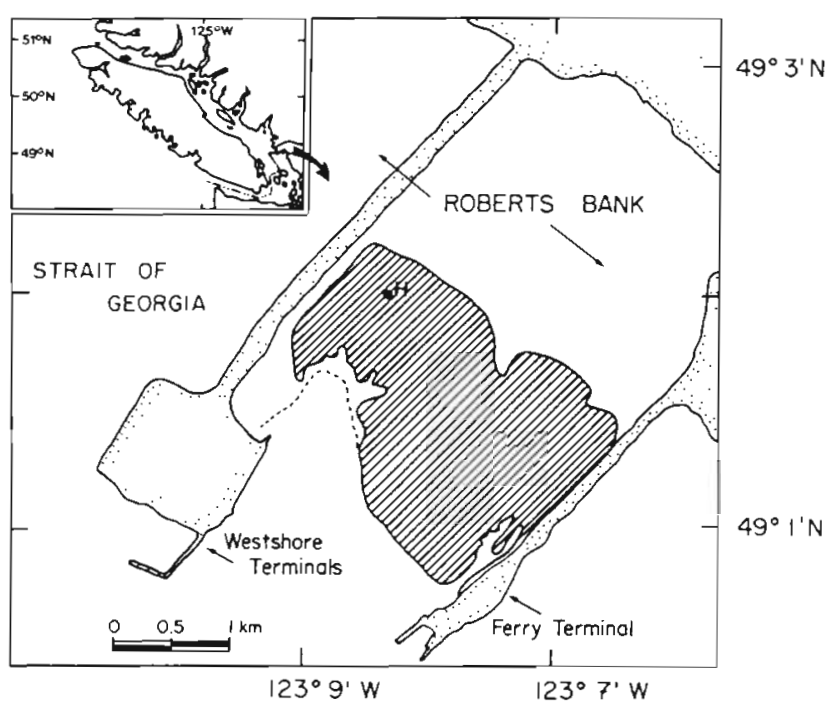

Fig. 1 Roberts Bank, British Columbia, Canada. Stn $\mathrm{H}$ is the location of harpacticoid copepod sample collection. Hatched area indicates extent of Zostera marina bed fafter Harrison 1987). Dashed curve shows seaward limit of shallow subtidal flat
1987. Harrison 1987). Maximum water depth at high tide is ca $3.2 \mathrm{~m}$. Sediments are fine sands (Swinbanks \& Luternauer 1987) with $>90 \%$ of the sediment between 75 and $354 \mu \mathrm{m}$ (Webb 1991b). These patterns of water depth and sediment grain size were consistent across the areal extent $(10 \mathrm{~m})$ sampled around Stn $\mathrm{H}$. Since the purpose of the sampling was to establish temporal rather than spatial patterns in copepod abundance, only this 1 station was occupied throughout the duration of the study allowing an increased number of replicate samples to be collected on each date. Collections were made at afternoon low tides at approximately 2 wk intervals from 22 January to 9 July 1986 and 24 January to 9 July 1987 . Since the diel tidal pattern varied concomitantly with the intersampling period, collections were made at a similar time of day throughout the sampling season. Sediment-surface water temperature at low tide during the sampling period varied from 6.1 to $14.8^{\circ} \mathrm{C}$ in 1986 , and 7.5 to $16.6^{\circ} \mathrm{C}$ in 1987 (Webb 1991a). Salinity varied from 19.5 to 30.3 PSU over the 2 yr with no obvious pattern, and was generally above 25 PSU.

Six Zostera marina leaves were sampled at randomly determined locations within $20 \mathrm{~m}$ of $\mathrm{Stn} \mathrm{H}$ on each sampling date. Locations were determined through random selection of a map coordinate (e.g. North, South, East, West) using a die and by taking a randomly chosen (using a random number table) number of steps (0 to 9) from the station marker in that direction. The first encountered shoot was selected for sampling and the longest leaf on the shoot was enclosed within a $30 \mathrm{~cm}$ long, $4 \mathrm{~cm}$ internal diameter PVC tube with a screw cap of $63 \mu \mathrm{m}$ Nitex mesh at one end. Any portion of the leaf protruding from the tube (if present) was cut off and the sampler capped. The sampler was retrieved and its contents rinsed into a jar using $40 \mu \mathrm{m}$ filtered seawater. The sample was then preserved by addition of a $4 \%$ formaldehyde/ $40 \mu \mathrm{m}$ filtered seawater solution. Relative age of the sampled leaf within the shoot was determined morphologically by observing the point of leaf insertion in the sheath in relation to the oldest (basal) leaf and the alternating pattern of leaf emergence. This procedure was repeated for the remaining 5 samples.

To sample sediment-dwelling copepods, 6 cores were taken at Stn H on each sampling date. Cores were taken at random coordinates within a $0.25 \mathrm{~m}^{2}$ quadrat divided into 100 squares of equal area. The quadrat was placed $1 \mathrm{~m}$ south of the station marker. Coordinates were picked randomly using a random number table. Cores were $5.3 \mathrm{~cm}^{2}$ in area and $5 \mathrm{~cm}$ in depth. This depth generally exceeded that of the redox potential discontinuity as determined by changes in sediment colour. Cores were extruded, placed into jars and preserved with a $4 \%$ formaldehyde $/ 40 \mu \mathrm{m}$ filtered seawater solution. 
In the laboratory, each leaf was shaken 5 times in the sample jar to remove any attached copepods. This procedure is $>99 \%$ efficient in retrieving copepods (Webb 1989). The leaf was removed and divided into, at most, $20 \mathrm{~cm}$ long segments. Length and width measurements were made to the nearest $0.5 \mathrm{~mm}$. Surface area was estimated arithmetically for each segment and then segment areas were summed to obtain sample area. Areas were calculated using both sides of leaf samples. The solution remaining in the sample jar was concentrated onto a $63 \mu \mathrm{m}$ sieve and rinsed with filtered seawater into a counting tray. For each sample, all copepodites of Harpacticus uniremis Kroyer, Tisbe cf. furcata (Baird) and Zaus aurelii Poppe were counted. Fifty individuals of each species, if present, were removed and identified to copepodite stage and gender. All remaining copepodites of other species were enumerated and 50 removed and identified to species and gross developmental stage (copepodite, adult male or female). Abundance of each species and stage in the sample was then estimated as a proportion of the total number of copepods. Nauplii were not enumerated. Copepodites of speciose genera (e.g. Amphiascus, Dactylopodia, Harpacticus, Tisbe) were identified to species based on comparison with copepodites from monospecific laboratory cultures.

To obtain copepods from the core samples, filtered seawater was added to the jars, the samples were swirled, the sediment allowed to settle for $5 \mathrm{~s}$ and the supernatant water decanted through a $63 \mu \mathrm{m}$ sieve. This procedure was repeated 5 times and is greater than $99 \%$ efficient in recovery of copepods (Webb 1989). The concentrated sample on the sieve was rinsed with filtered seawater into a counting tray and analysis proceeded identically as with the leaf samples.

To allow comparison of harpacticoid densities between seagrass and sediment samples, abundances in each sample (leaf and sediment) were converted to no. $\mathrm{cm}^{-2}$ sediment area. This was accomplished for seagrass-dwelling harpacticoids using collected data on abundances in samples, relative leaf age of samples, intrashoot copepod distributions, shoot density and leaf areas [see Webb $(1989,1990)$ for a detailed description of this methodology and the appropriate data]. Since core area was known, sediment harpacticoid densities were directly determined.

\section{RESULTS}

A total of 55 harpacticoid species in 13 families were observed, in either leaf or sediment samples, during 1 or both years of this study (Webb 1989). The family Diosaccidae was dominant in terms of number of species (16). Because of the large number of species, only epiphytic species with densities at their abundance peak of $\geq 10 \%$ of the total harpacticoid numbers on that sampling date in either year are discussed further. Epiphytic species are defined as those more abundant on seagrass leaves than in the sediment or species that undertake the majority of pre-adult development (as evidenced by copepodite numbers) on the leaves. The results concerning total harpacticoids and species meeting the inclusion criterion will be considered further on an individual basis.

\section{Total harpacticoids}

In 1986, seagrass-dwelling harpacticoids had their highest mean density on 22 January, when over $3500 \mathrm{~cm}^{-2}$ sediment were found (Fig. 2a). A secondary peak was observed on 4 March with numbers tapering off towards July. Maximal sediment densities were 2 orders of magnitude lower and peak mean density was observed on 10 June, after which numbers declined to late winter levels (Fig. 2c).

Maximum mean density of seagrass copepods was much lower in 1987 (under $70 \mathrm{~cm}^{-2}$ sediment on 28 Mayl with low numbers observed until 30 April (Fig. 2b). Numbers declined after the peak but remained higher than pre-30 April values. Peak mean sediment-dwelling copepod abundance was observed on 14 May at a similar density to 1986 (Fig. 2d). Densities in late January-early February were higher than in 1986 and a decline after the May peak was not observed.

\section{Amonardia normani (Brady)}

In 1986, Amonardia normani mean density on the leaves peaked on 9 July, at just under 7 ind. $\mathrm{cm}^{-2}$ sediment (Fig. 3a). This maximum was composed mainly of copepodites. Densities in the sediment were comparatively low (Fig. 3c). Individuals in the sediment appeared at the same time as on the leaves.

This species had a unimodal peak on the leaves on 28 May in 1987 at just under 5 ind. $\mathrm{cm}^{-2}$ sediment (Fig. 3b). Similar to 1986, this peak was composed of copepodites. Sediment densities were comparatively low, as in 1986, and individuals again appeared concurrently with those on the leaves (Fig. 3d).

\section{Amphiascus undosus Lang}

On the seagrass leaves, mean density of this species had a maximum on 4 March in 1986 of over 15 ind. $\mathrm{cm}^{-2}$ sediment followed by a sharp decline, with a 

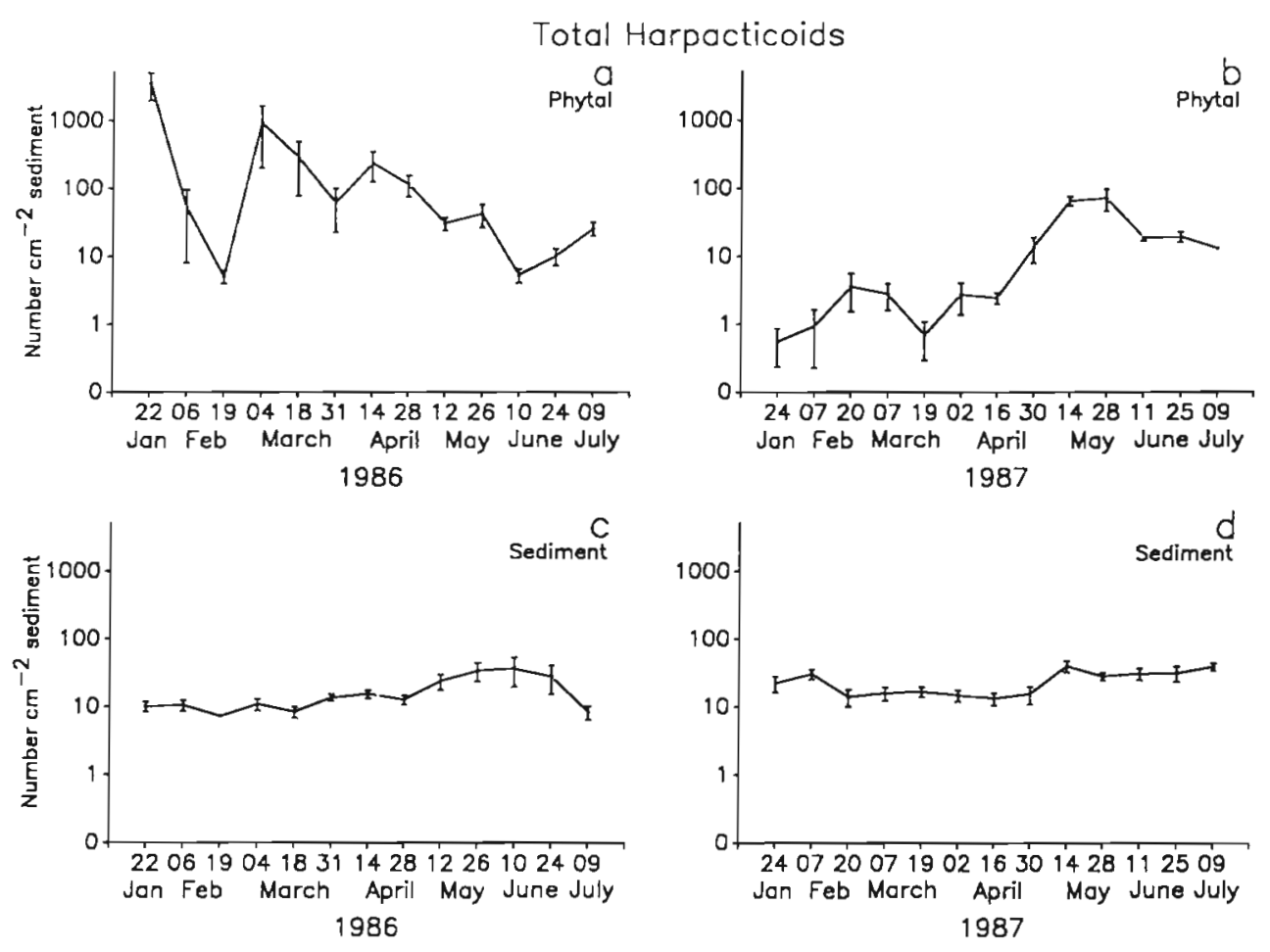

Fig. 2. Abundance of total harpacticoid copepods on Zostera marina leaves at Stn H in (a) 1986 and (b) 1987 and in the sediment in (c) 1986 and (d) 1987. Plotted values are the mean \pm 1 SE, $n=6$
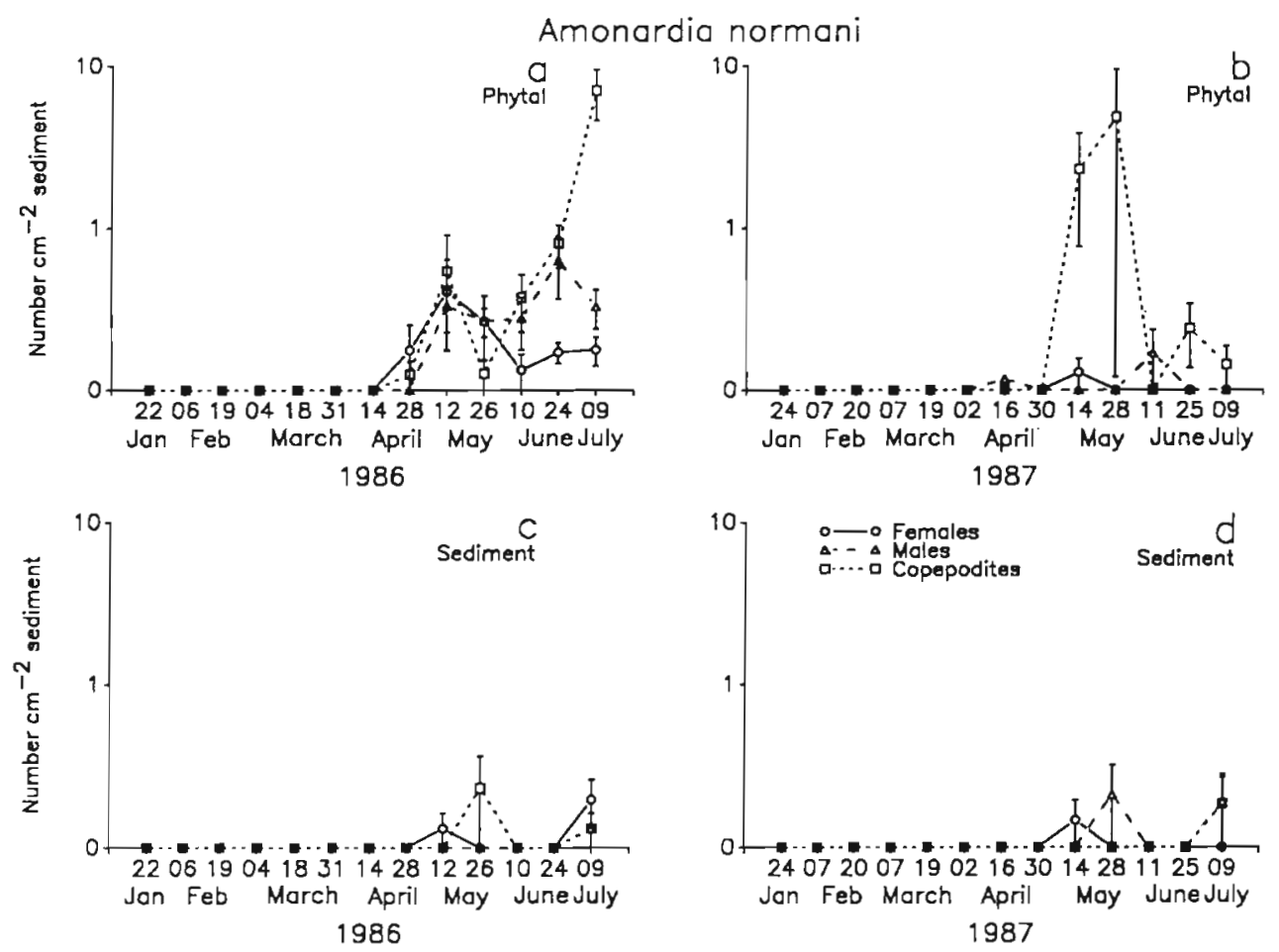

Fig. 3. Amonardia normani. Copepodite, male and female abundance on Zostera marina leaves at Stn H in (a) 1986 and (b) 1987 and in the sediment in (c) 1986 and (d) 1987 . Plotted values are the mean $\pm 1 \mathrm{SE}, \mathrm{n}=6$ 
secondary increase occurring after 28 April (Fig. 4a). The 4 March peak was of copepodites which was followed by an increase in adults. The second increase was initially composed of females followed by copepodites. The sediment harboured mainly females throughout the sampling period (Fig. 4c). Female density in the sediment declined from 22 January to a minimum on 14 April, then increased at the same time as the leaf population.

In 1987, the leaf population of this species did not increase until late April and reached a maximum of just under 10 copepods $\mathrm{cm}^{-2}$ sediment on 14 May (Fig. 4b). The leaf population was composed mainly of females with copepodite numbers highest after 11 June. The sediment population in 1987 was denser with a maximum of just under $15 \mathrm{~cm}^{-2}$ sediment on 7 February which declined towards summer (Fig. $4 \mathrm{~d}$ ). The sediment population was also composed mainly of females.

\section{Dactylopodia crassipes Lang}

In 1986, this species on the leaves exhibited sporadic density maxima of between 10 and 20 ind $\mathrm{cm}^{-2}$ sediment during the period from 4 March to 26 May (Fig. $5 a)$. These sporadic maxima were generally because of increases in males with an underlying long-term increase in copepodites and females. The long-term pattern without the sporadic increases in males was observed at lower densities in the sediment (Fig. 5c). Copepodites were observed in the sediment from 22 January onwards.

On the leaves in 1987, a peak of just over 5 copepods $\mathrm{cm}^{-2}$ sediment was observed on 11 June (Fig. 5b). This peak was mainly because of an increase in copepodites. In the sediments, a smaller peak of copepodites, males and females together was seen on 25 June (Fig. 5d). Copepodites were present in the sediments during late winter-early spring when leaf populations were extremely low.

\section{Harpacticus uniremis Kroyer}

In 1986, peak mean density of Harpacticus uniremis on leaves was just under 5 ind. $\mathrm{cm}^{-2}$ sediment on 28 April (Fig. 6a). Peaks in adult density in late April and May were preceded by large numbers of copepodites. Abundance of $H$. uniremis in the sediment was considerably lower $\left(<0.5\right.$ ind $\mathrm{cm}^{-2}$ sediment) and was mainly composed of adult females (Fig. 6c). Adult females in the sediment were most numerous after the peak in female abundance on the seagrass leaves.

The temporal distribution of seagrass-dwelling Harpacticus uniremis was more restricted in 1987 with a maximum just slightly less than that in 1986 on 14 May
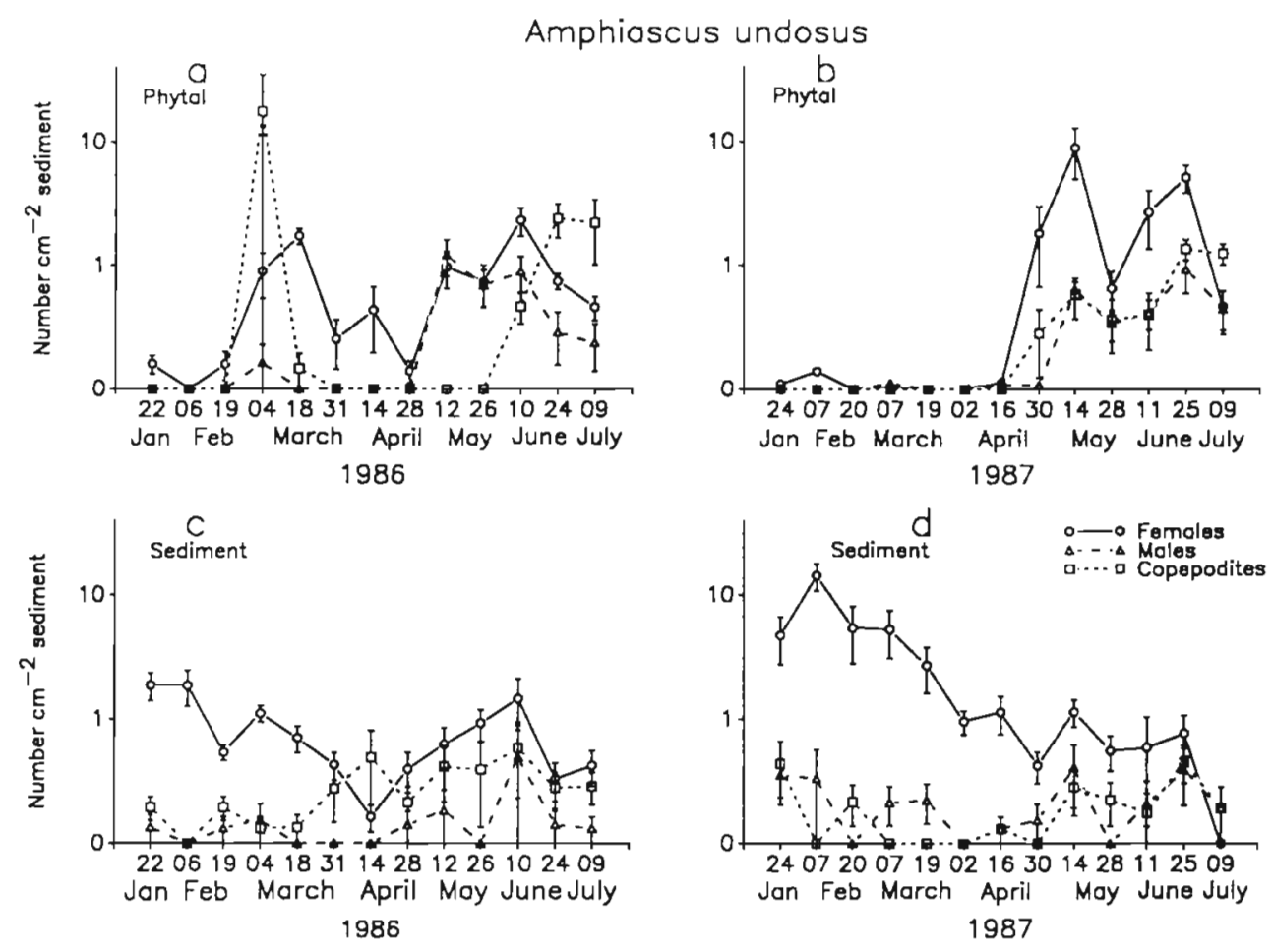

Fig. 4. As Fig. 3 but for Amphiascus undosus 
(Fig. 6b). Peaks in copepodites, males and females coincided. Sediment densities were also low in 1987 compared to those on the leaves (Fig. 6d). The peak in females in the sediment after the leaf peak was noted as in 1986 .

\section{Heterolaophonte variabilis Lang}

In 1986, this species showed a maximum on the leaves of just over 12 ind. $\mathrm{cm}^{-2}$ sediment on 9 July, which was composed mainly of copepodites (Fig. 7 a). Sediment densities were comparatively low (Fig. $7 \mathrm{c}$ ).

The 1987 maximum on the leaves was slightly lower (just under 10 ind. $\mathrm{cm}^{-2}$ sediment) and the increase started earlier than in 1986 (14 May in 1987 versus 24 June in 1986) (Fig. 7b). The 1987 increase was composed of a greater proportion of females than in 1986 . Sediment densities were again comparatively low, with mostly adult females observed (Fig $7 \mathrm{~d}$ ).

\section{Mesochra pygmaea (Claus)}

This species was the main contributor to the maximum of total harpacticoid copepods on the leaves on 22 January in 1986. A peak of just over 2700 ind. $\mathrm{cm}^{-2}$ sediment was observed, composed almost entirely of females (Fig. 8a). A secondary peak on 4 March was also composed of females. Females were observed until 24 June. Sediment densities were comparatively low, with maximum abundance observed on 14 April (Fig. 8c).

Mean densities in 1987 were much lower on leaves, with a maximum of just under $3.5 \mathrm{ind} . \mathrm{cm}^{-2}$ sediment on 11 June (Fig. 8b). Females predominated until 30 April after which copepodites and males became proportionately more abundant. Sediment densities were maximal on 24 January at a similar level to the leaf maximum after which numbers declined throughout the sampling period (Fig. 8d). Sediment samples contained mostly females.

\section{Tisbe cf. furcata (Baird)}

Tisbe cf. furcata mean densities in 1986 on Zostera leaves were maximal on 22 January at $>750$ ind. $\mathrm{cm}^{-2}$ sediment (Fig. 9a). A smaller secondary peak was seen on 18 March. These peaks were mainly caused by elevated abundances of copepodites. A third minor peak of copepodites was observed on 28 April, and was followed by increases in adult male and female densities. Sediment densities peaked at just over 1 ind. $\mathrm{cm}^{-2}$ sediment on 31 March (Fig. 9c).

Abundance was much lower and temporally more discrete on leaves in 1987, with a maximum of just over
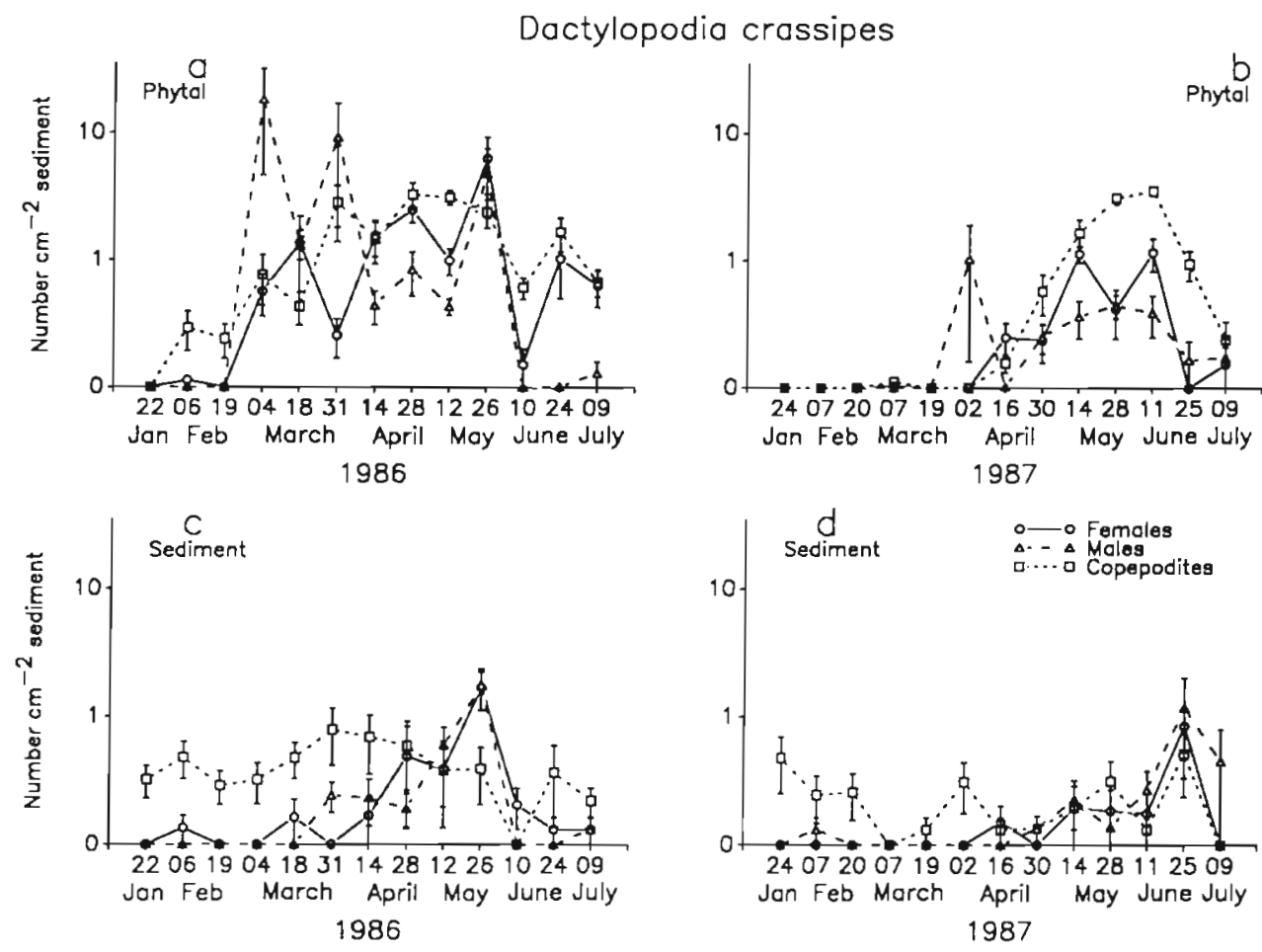

Fig. 5. As Fig. 3 but for Dactylopodia crassipes 

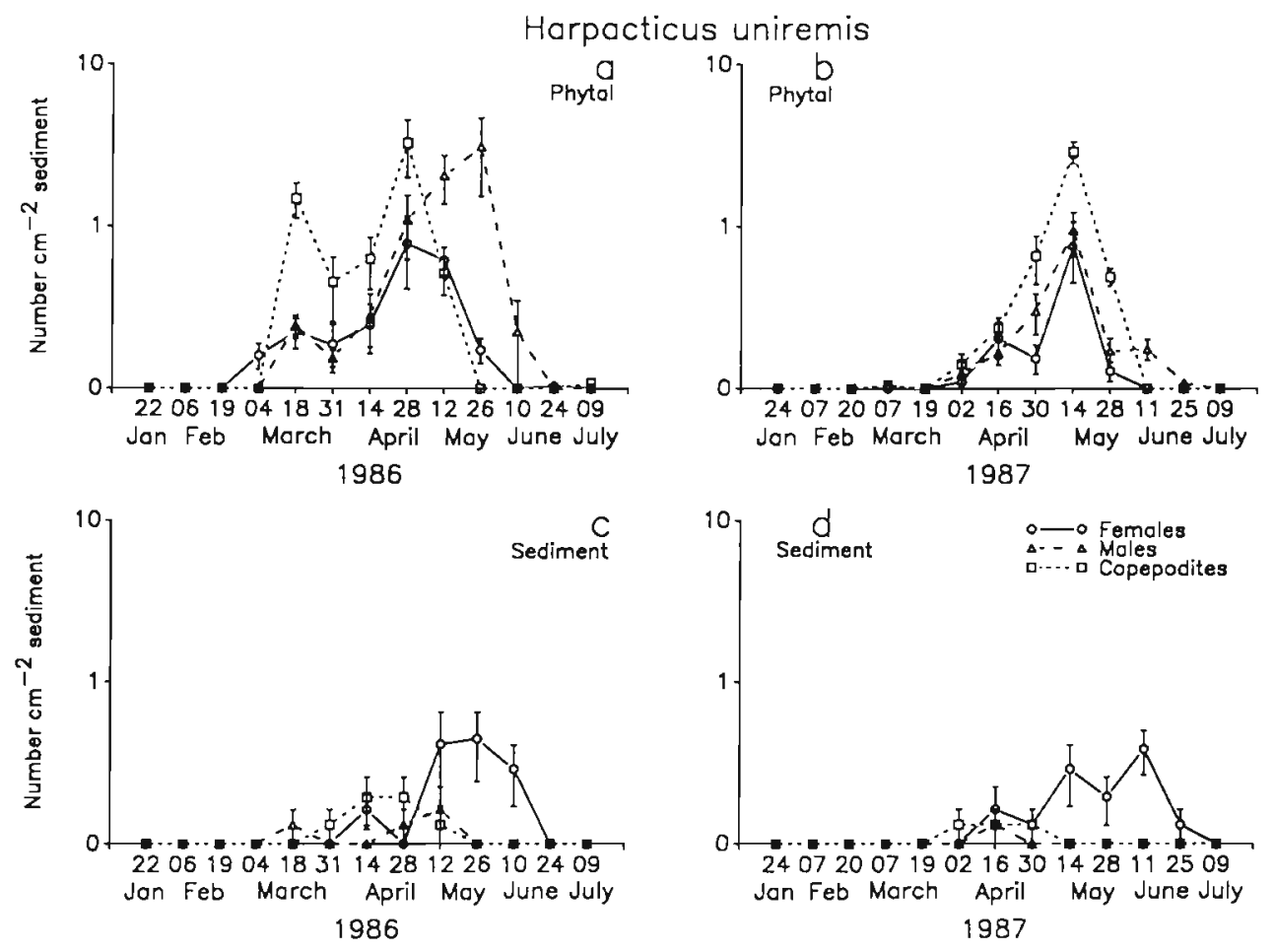

Fig. 6. As Fig. 3 but for Harpacticus uniremis
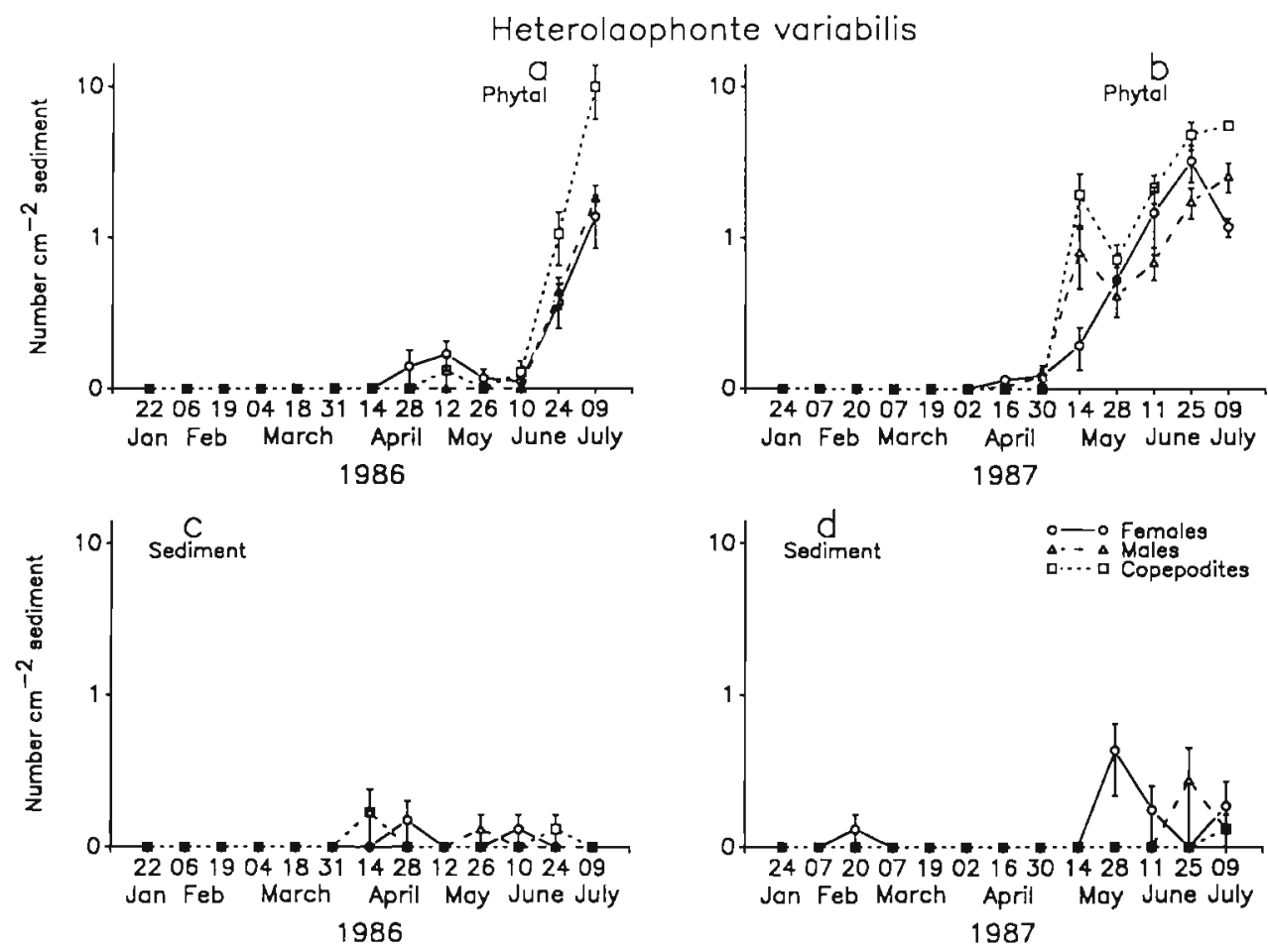

Fig. 7. As Fig. 3 but for Heterolaophonte variabilis 
20 ind. $\mathrm{cm}^{-2}$ sediment on 14 May (Fig. 9b). Peaks in copepodites, males and females coincided. Small numbers were again observed in the sediment as in 1986 (Fig. 9d), but the density maximum coincided with that on the leaves.

\section{Zaus aurelii Poppe}

In 1986, Zaus aurelii mean abundance on leaves was unimodal with a peak of over 200 copepods $\mathrm{cm}^{-2}$ sediment on 14 April (Fig. 10a). Maxima of copepodites and females were on 14 April with the male maximum on the next sampling date. This species was rare in the sediments (Fig. 10c).

Abundance was also unimodal on leaves in 1987. with a maximum mean density of just over 40 ind. $\mathrm{cm}^{-2}$ sediment on 28 May (Fig. 10b). Coincidental peaks in males and females were observed with a copepodite peak preceding. Zaus aurelii was not found in sediment samples from 1987.

\section{DISCUSSION}

Of the 55 harpacticoid copepod species encountered over both sampling years, 8 species met the cutoff criterion for detailed analysis. Amonardia normani, Amphiascus undosus, Dactylopodia crassipes, Har- pacticus uniremis, Heterolaophonte variabilis, Mesochra pygmaea, Tisbe cf. furcata and Zaus aurelii were considered to be epiphytic since they were found to be more abundant on seagrass leaves than in the underlying sediment or to undergo their majority of preadult development (as evidenced by copepodite numbers) in this subhabitat (e.g. A. undosus, M. pygmaea). This harpacticoid fauna is similar in the composition of families and genera to other epiphytic faunas in temperate waters of the northern hemisphere (e.g. Hicks 1980, Hicks 1985, Johnson \& Scheibling 1987). The sediment harpacticoid community was very different from the epiphytic fauna and dominated in numbers by the Ectinosomid Halectinosoma sp. in both years (Webb 1989). Community dominance by the Ectinosomatidae is not uncommon in shallow soft-sediment habitats (see Hicks \& Coull 1983).

In 1986, the highest total leaf copepod densities occurred before 18 March. These abundances were extremely high, especially on the first sampling date. This peak was mainly caused by high numbers of Mesochra pygmaed and Tisbe cf. furcata. Densities were lower in 1987 but leaf-dwelling harpacticoid abundance, on a per unit sediment area basis, generally exceeds sediment copepod densities at this study site, especially during the period of maximum abundance. This is generally the pattern in most shallow subtidal areas (see Hicks \& Coull 1983).
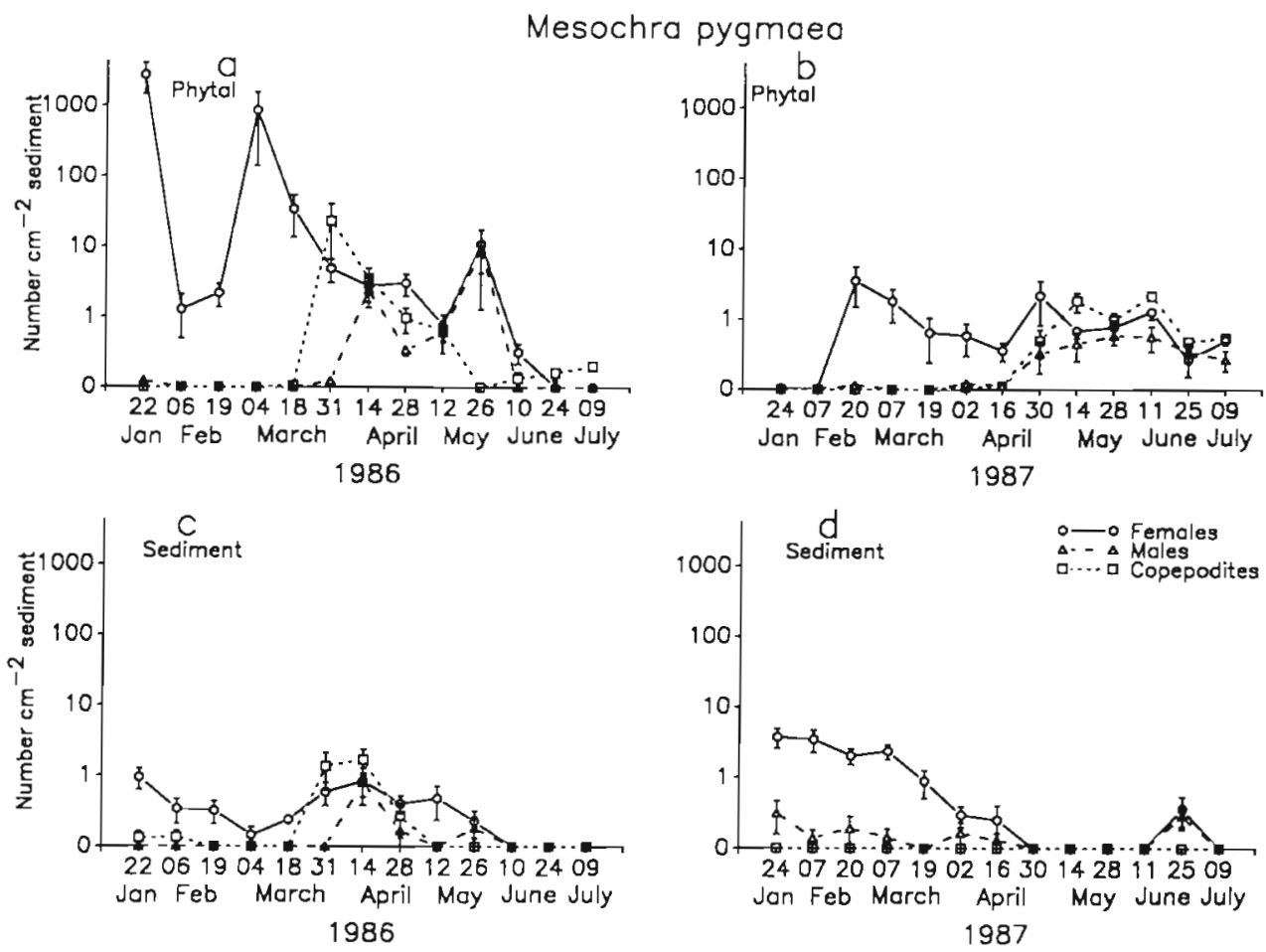

Fig. 8. As Fig. 3 but for Mesochra pygmaea 
Tisbe cf. furcata
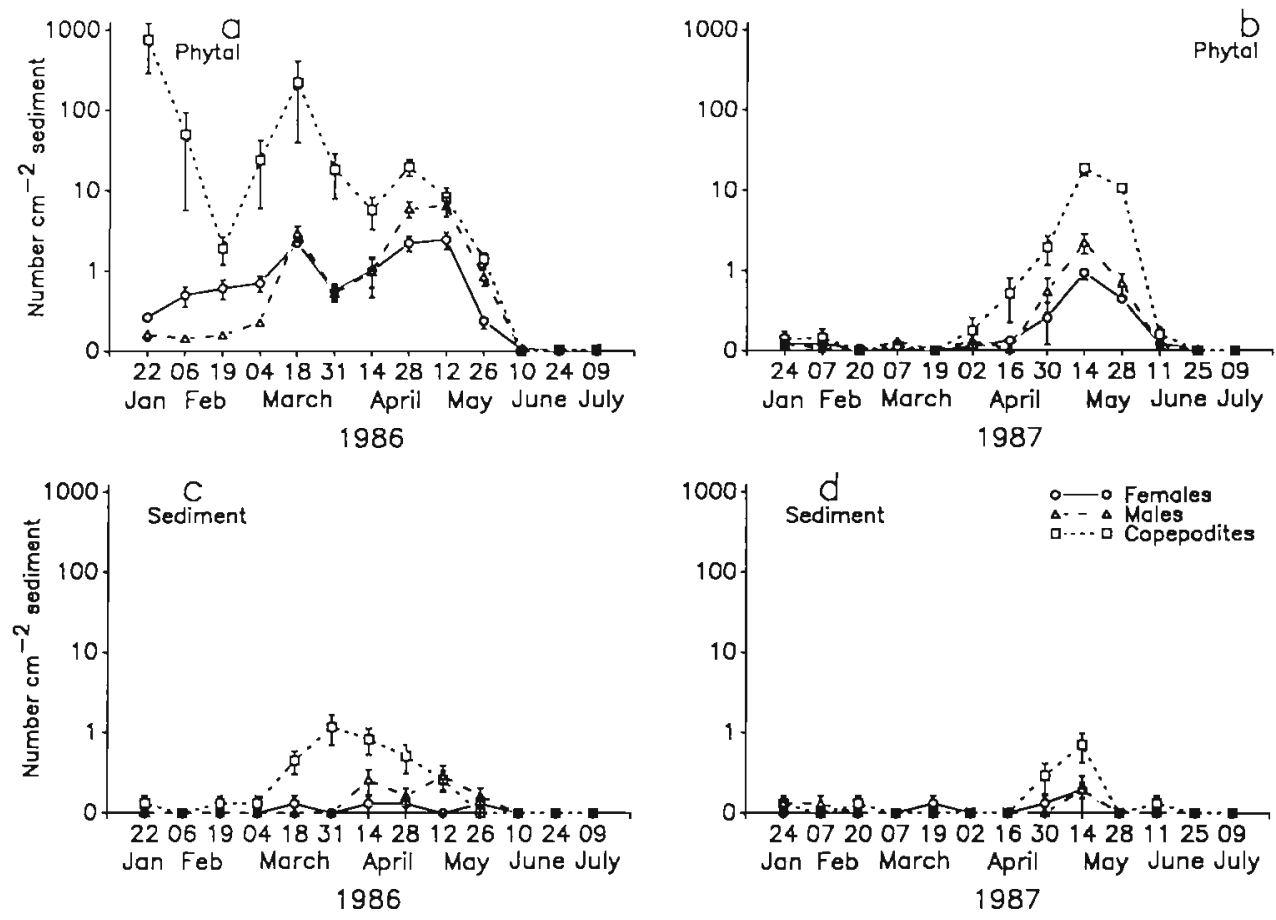

Fig. 9. As Fig. 3 but for Tisbe cf. furcata
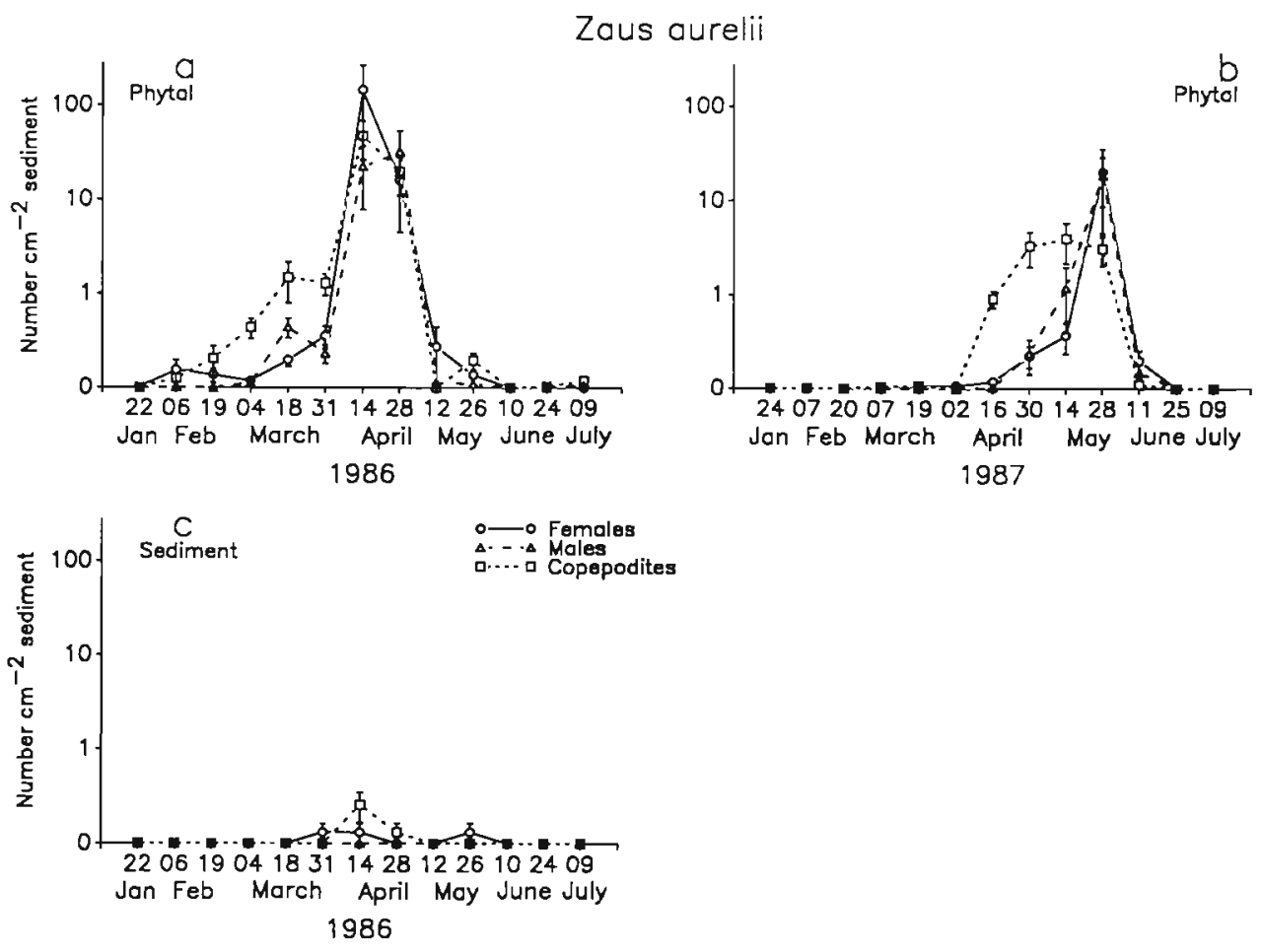

Fig. 10. Zaus aurelii. Copepodite, male and female abundance at Stn H on Zostera marina leaves in (a) 1986 and (b) 1987, and (c) in sediment in 1986. Plotted values are the mean $\pm 1 \mathrm{SE}, \mathrm{n}=6$ 
Most species in the leaf harpacticoid community, excluding Mesochra pygmaea and Tisbe cf. furcata in 1986, exhibited a general increase in abundance starting in early to mid March in 1986 and in early to mid April in 1987. A similar increase in the spring was also seen in the sediment community. A spring 'bloom' of harpacticoid copepods is commonly observed in epiphytic and sediment communities (e.g. Hagerman 1966, Kito 1977, Rudnick et al. 1985, Bell et al. 1986. Johnson \& Scheibling 1987, D'Amours 1988). This pattern may be related to increases in temperature and light levels during the spring leading to enhanced bacterial and microalgal production. Bacteria and microalgae are considered to be the major food source for marine harpacticoid copepods (see Hicks \& Coull 1983). At this study site, the spring harpacticoid 'bloom' may be predictably triggered by shifts in tidal pattern which lead to increased light levels and temperature (D'Amours 1988). In 1986, Mesochra pygmaea and Tisbe cf. furcata attained their highest densities on the first sampling date in January. However, these 2 species also exhibited smaller increases in abundance in March and April 1986, coincident with the general increase of other species in the community.

In both 1986 and 1987, successional patterns of harpacticoid species dominance were observed on the seagrass leaves. However, these patterns differed dramatically between years. In 1986, peaks in both Mesochra pygmaea and Tisbe cf. furcata density on 22 January were followed by the maximum densities of Amphiascus undosus and Dactylopodia crassipes on 4 March, Zaus aurelii on 14 April, Harpacticus uniremis on 28 April, and Amonardia normani and Heterolaophonte variabilis on 9 July. In 1987, the first maximums observed were on 14 May for $A$. undosus, $H$. uniremis and $T$. cf. furcata, followed by density peaks of $A$. normani and $Z$. aurelii on 28 May, $D$. crassipes and $M$. pygmaea on 11 June, and $H$. variabilis on 25 June. Apart from the difference in timing of the abundance maxima for most species between the 2 years, the successional order is different. The only consistency between the $2 y \mathrm{r}$ was that $H$. variabilis was always the last species to display a density maximum. The differences observed between the 2 years are surprising given the similarities of basic structure found in seasonal patterns in multi-year harpacticoid copepod data sets (e.g. Coull \& Dudley 1985). We have no explanation for the dissimilarity in copepod abundance patterns between 1986 and 1987 . However, the high densities observed in winter in the 1986 samples suggest that conditions were more favourable for growth in that year. This is also indicated by the fact that most species increased in abundance earlier in 1986 than in 1987. Temperature records, however, indicate that the winter in 1986 was colder than that in
1987 (Webb 1991a). It is possible that events occurring earlier in the winter than sampled here are important in defining later patterns in abundance, or that the patterns themselves are stochastic. It is possible that the successional sequence is determined through the timing of sudden influxes of copepods from the subtidal caused by increased wind or wave activity.

Some of the epiphytic species populations on the leaves may have been seeded from females found in the sediment earlier in the sampling season. However, reproduction (as deduced from increases in the number of copepodites) seems to take place primarily on the leaves. This appears to be the case for Amphiascus undosus and Dactylopodia crassipes in both years, and Mesochra pygmaea in 1987. For $A$. undosus and $M$. pygmaea, the leaf population appears to have been initiated from females present in the sediment in late January and February which had presumably overwintered there. Females appeared on the leaves without copepodites being present beforehand which implies immigration, with the sediment females being a likely source. The $D$. crassipes leaf population was also probably seeded from the sediment. However, copepodites were present in the sediment in January and February. They were male and female fifth stage copepodites which were encysted in a manner similar to that described by Coull \& Grant (1981) for Heteropsyllus sp. The $D$. crassipes within the cysts had a bent urosome like the description for Heteropsyllus sp. and droplets (presumably lipid) could be seen within the copepods. A different pattern was observed for Harpacticus uniremis in both years. Adult female density in the sediment peaked about 1 mo later than on the leaves. Few copepodites were present previously, suggesting that this was not a separate subpopulation. It is most likely that the females moved from the leaves to the sediment surface. None of the females in the sediment were found to be gravid (Webb 1989), suggesting further recruitment of this species in the sediment was negligible during the sampling period. Overall, the distribution of these 4 species $(50 \%$ of the total number of dominant species in the community) implies that individuals of epiphytic species may commonly spend portions of the year in the sediments, perhaps as a mechanism to avoid stress. One record of habitat switching of this kind is found for the harpacticoid Thalestris longimana Claus in England where females overwinter subtidally but reproductive activity occurs only in the summer on intertidal macroalgae (Hicks 1979). The dominant harpacticoid species (Bulbamphiascus sp.) in a New Zealand seagrass bed also appears to recruit to artificial seagrass leaves from the sediment (Bell \& Hicks 1991).

At this study site, although densities of Zostera marina shoots are lower in winter than summer (Webb 
1989), enough habitat is still present in early spring to allow space for recruitment of epiphytic harpacticoids. This is in contrast to the dynamics of $Z$. japonica on Roberts Bank, which declines to extremely low numbers during the winter (D. G. Webb pers. obs.). If $Z$. japonica becomes more prevalent, this may have a significant impact on the recruitment patterns of the epiphytic copepods and possibly the growth of juvenile salmonids in the area, which rely on epiphytic harpacticoids as their primary food source (Webb 1991a).

Data presented herein provide some of the first information on temporal patterns of abundance of seagrass-dwelling temperate harpacticoid copepod species during the winter-spring transition. It appears that between-year patterns in seagrass-dwelling copepod abundance are more variable than those observed in sediment-dwelling species. Also, some leafdwelling copepod populations appear to be seeded from overwintering individuals in the sediment. Possible movement to the sediment from the leaves was observed for 1 species. Results obtained here underscore the importance of sampling multiple potential subhabitats in seagrass beds when assessing the dynamics of the harpacticoid copepod community (Bell et al. 1984). Elucidation of the factors affecting successional patterns and movement to and from the leaf surface should be considered in further research on seagrass-dwelling copepods.

Acknowledgements. We thank D. D'Amours, M. St. John and $M$. Gollner for their assistance with the field sampling. A. Metaxas and D. D'Amours provided numerous criticisms, insights and often animated discussions on this research. A. Metaxas conscientiously criticized and improved early versions of the manuscript. W. P. Cochlan applied his artistry to Fig. 1. We also thank J. R. Cordell, C. D. Levings, C. A. Simenstad and an anonymous reviewer for their helpful comments on the manuscript. Logistical support for this study was provided by NSERC Operating Grants to T.R.P. Personal support was provided by a NSERC Postgraduate Scholarship, Fonds FCAC (Quebec), the Kit Malkin Scholarship, a Summer University of British Columbia Graduate Fellowship and the Capt. T. H. Byrne Scholarship to D.G.W. and NSERC Operating Grants to T.R.P.

\section{LITERATURE CITED}

Beckley, L. E., McLachlan, A. (1980). Studies on the littoral seaweed epifauna of St. Croix Island 2. Composition and summer standing stock. S. Afr. J. Zool. 15: 170-176

Bell, S. S., Hicks, G. R. F. (1991). Marine landscapes and faunal recruitment: a field test with seagrasses and copepods. Mar. Ecol. Prog. Ser. 73: 61-68

Bell, S. S., Kern, J. C., Walters, K. (1986). Sampling for meiofaunal taxa in seagrass systems: lessons from studies of a subtropical Florida estuary, USA. In: Thompson, M.-F., Sarojini, R., Nagabhushanam, R. (eds.) Biology of benthic marine organisms. Techniques and methods as applied to the Indian Ocean. A. A. Balkema, Rotterdam, p. 239-245
Bell, S. S., Walters, K., Kern, J. C. (1984). Meiofauna from seagrass habitats: a review and prospectus for future research. Estuaries 7: 331-338

Caine, E. A. (1980). Ecology of two littoral species of caprellid amphipods (Crustacea) from Washington, USA. Mar. Biol. 56: $327-335$

Colman, J. (1940). On the faunas inhabiting intertidal seaweeds. J mar biol. Ass. U.K. 24: 129-183

Coull, B. C., Dudley, B. W. (1985). Dynamics of meiobenthic copepod populations: a long-term study (1973-1983). Mar. Ecol. Prog. Ser. 24: 219-229

Coull, B. C., Grant, J. (1981). Encystment discovered in a marine copepod. Science 212: 342-344

D'Amours, D. (1987). Trophic phasing of juvenile chum salmon Oncorhynchus keta Walbaum and harpacticoid copepods in the Fraser River Estuary. British Columbia. Ph.D. thesis, University of British Columbia, Vancouver

D'Amours, D. (1988). Temperature beat on a tidal flat: potential cue for harpacticoid bloom. Neth. J. Sea Res. 22: 301-305

Gee, J. M. (1989). An ecological and economic review of meiofauna as food for fish. Zool. J. Linn. Soc. 96: 243-261

Hagerman, L. (1966). The macro- and microfauna associated with Fucus serratus L., with some ecological remarks. Ophelia 3: 1-43

Harrison, P. G. (1987). Natural expansion and experimental manipulation of seagrass (Zostera spp.) abundance and the response of infaunal invertebrates. Estuar. coast. Shelf Sci. 24: 799-812

Hicks, G. R. F. (1977). Species composition and zoogeography of marine phytal harpacticoid copepods from Cook Strait, and their contribution to total phytal meiofauna. N.Z. J. mar. Freshwat. Res. 11: 441-469

Hicks, G. R. F. (1979). Pattern and strategy in the reproductive cycles of benthic harpacticoid copepods. In: Naylor, E., Hartnoll, R. G. (eds.) Cyclic phenomena in marine plants and animals. Pergamon, Oxford, p. 139-147

Hicks, G. R. F. (1980). Structure of phytal harpacticoid copepod assemblages and the influence of habitat complexity and turbidity. J. exp. mar. Biol. Ecol. 44: 157-192

Hicks, G. R. F. (1985). Meiofauna associated with rocky shore algae. In: Moore, P.G., Seed, R. (eds.) The ecology of rocky coasts. Hodder and Stoughton, London, p. 36-56

Hicks, G. R. F. (1986). Distribution and behaviour of meiofaunal copepods inside and outside seagrass beds. Mar. Ecol. Prog. Ser. 31: 159-170

Hicks, G. R. F., Coull, B. C. (1983). The ecology of marine meiobenthic harpacticoid copepods. Oceanogr. mar. Biol. A. Rev. 21:67-175

Johnson, S. C., Scheibling, R. E. (1987). Structure and dynamics of epifaunal assemblages on intertidal macroalgae Ascophyllum nodosum and Fucus vesiculosus in Nova Scotia, Canada. Mar. Ecol. Prog. Ser. 37: 209-227

Kito, K. (1977). Phytal animals in the Sargassum confusum region in Oshoro Bay, Hokkaido: phenology of harpacticoid copepods. J. Fac. Sci. Hokkaido Univ., Ser. VI, Zool. 20: $691-696$

Lewis, J. B., Hollingworth, C. E. (1982). Leaf epifauna of the seagrass Thalassia testudinum. Mar. Biol. 71: 41-49

Mukai, H. (1971). The phytal animals on the thalli of Sargassum serratifolium in the Sargassum region, with reference to their seasonal fluctuations. Mar. Biol. 8: 170-182

Nagle, J. S. (1968). Distribution of the epibiota of macroepibenthic plants. Contr. mar. Sci. 3: 105-144

Novak, R. (1982). Spatial and seasonal distribution of the meiofauna in the seagrass Posidonia oceanica. Neth. J. Sea Res. 16: 380-388

Pallares, R. E., Hall, M. A. (1974). Analisis bioestadistico- 
ecologico de la fauna de copepodos asociados a los bosques de Macrocystis pyrifera. Physis Sec. A, Oceanos Sus. Org. 33: 275-319, 409-432

Rudnick, D. T., Elmgren, R., Frithsen, J. B. (1985). Meiofaunal prominence and benthic seasonality in a coastal marine ecosystem. Oecologia 67: 157-168

Swinbanks, D. D., Luternauer, J. L. (1987). Burrow distribution of Thalassinidean shrimp on a Fraser delta tidal flat, British Columbia. J. Paleontol. 61: 315-332

Webb, D. G. (1989). Predation by juvenile salmonids on harpacticoid copepods in a shallow subtidal seagrass bed effects on copepod community structure and dynamics. $\mathrm{Ph}$.D. thesis, University of British Columbia, Vancouver

Webb, D. G. (1990). Intrashoot distributions of leaf dwelling harpacticoid copepods on the seagrass Zostera marina L.:

This article was presented by C. D. Levings, West Vancouver, B. C., Canada implications for sampling design. Hydrobiologia 206: $155-162$

Webb, D. G. (1991a). Effect of predation by juvenile Pacific salmon on marine harpacticoid copepods. I. Comparisons of patterns of copepod mortality with patterns of salmon consumption. Mar. Ecol. Prog. Ser. 72: 25-36

Webb, D. G. (1991b). Effect of predation by juvenile Pacific salmon on marine harpacticoid copepods. II. Predator density manipulation experiments. Mar. Ecol. Prog. Ser. 72: $37-47$

Wieser, W. (1952). Investigations on the microfauna inhabiting seaweeds on rocky coasts IV. Studies on the vertical distribution of the fauna inhabiting seaweeds below the Plymouth Laboratory. J. mar. biol. Ass. U.K. 31: $145-174$

Manuscript first received: September 12, 1991 Revised version accepted: March 31, 1992 